This is a post-peer-review, pre-copyedit version of an article published in Trees.

The final authenticated version is available online at:

https://doi.org/10.1007/s00468-015-1176-5.

\title{
Complex climate constraints of upper treeline formation in the Pyrenees
}

Ester González de Andrés $^{1}$, J. Julio Camarero ${ }^{2 *}$ and Ulf Büntgen ${ }^{3,4,5}$

${ }^{1}$ Departamento de Ciencias del Medio Natural, Universidad Pública de Navarra, Campus Arrosadía S/N, E-31006 Pamplona, Spain.

${ }^{2}$ Instituto Pirenaico de Ecología, CSIC (IPE-CSIC). Avda. Montañana 1005, Apdo. 202, E-50192 Zaragoza, Spain.

${ }^{3}$ Swiss Federal Research Institute WSL, Zuercherstrasse 111, 8903 Birmensdorf, Switzerland.

${ }^{4}$ Oeschger Centre for Climate Change Research (OCCR), University of Bern, CH-3012 Bern, Switzerland.

${ }^{5}$ Global Change Research Centre AS CR, v.v.i., Bělidla 986/4a, CZ-60300 Brno, Czech Republic.

*Corresponding author:

Dr. J. Julio Camarero

Instituto Pirenaico de Ecología, IPE-CSIC.

Avenida Montañana 1005, Zaragoza E-50192, Spain.

E-mail: jjcamarero@ipe.csic.es

Tel. 0034-976-716031, Fax: 0034-976-716019

Author Contribution Statement: U. Büntgen performed fiel sampling. E. González carried out all analyses under the supervision of the other authors. All authors contributed to the writing of the paper and the discussion of findings.

Conflict of Interest: J. Julio Camarero was supported by projects 387/2011 (OAPN, Agriculture an Environment Ministry, Spain) and CGL2011-26654 (Economy and Innovation Ministry, Spain). U. Büntgen was further supported by the Operational Programme of Education for Competitiveness of the Ministry of Education, Youth, and Sports of the Czech Republic (No. CZ.1.07/2.3.00/20.0248).

The authors declare that they have no conflict of interest. 


\section{Abstract}

Alpine treelines are often induced by a threshold of minimum temperatures above which tree growth is generally not possible anymore. However, this worldwide pattern may not account for more drought-prone mountains, where changes in precipitation can also affect ecosystem functioning and productivity at higher elevations. Here, we aim to determine if tree ring formation in ecotones along the Pyrenees indeed primarily depends on temperature means or also reflects hydroclimatic changes. The mean duration of the growing season at Pyrenean treelines was 177 days lasting from mid May to early November, which corresponds to a mean root-zone temperature of $8.2^{\circ} \mathrm{C}$. Temperatures during the early and late growing season were most critical for mountain pine growth at highest elevations, and above average spring temperatures also contributed to radial enlargement of tracheids. Sites showing more similar soil temperatures also presented more alike long-term growth trends indicating that local conditions trace regional influences on growth. Nevertheless, more wet conditions in summer enhanced growth at treelines subjected to more Mediterranean influence and therefore having a higher summer water deficit. A broader perspective reveals that soil moisture availability during spring and summer, however, also influenced ring width formation at other treelines located in mid-latitude mountains separating temperate and semi-arid biomes. Our results suggest re-evaluating the idea of purely temperaturelimited treelines, especially in mid-latitude mountains that experience moisture seasonality or where precipitation decreases with increasing elevation.

Keywords: basal area increment; drought stress; Mediterranean; Pinus uncinata; temperature; treeline.

Key Message: In the Pyrenees low temperature and scarce precipitation limit radial growth at treeline. The climatic drivers of treeline formation in mid-latitude mountains should consider temperature but also moisture variability. 


\section{Introduction}

Alpine treelines have attracted and puzzled geographers and ecologists for centuries (Arno 1984; Holtmeier and Broll 2005; Körner 2012). Such worldwide and conspicuous limits of high-altitude forests have been used as a monitor of temperature fluctuations across wide spatial and temporal scales (e.g. Shiyatov 2003). These estimates are based on the assumption that the treeline ecotone (here considered as the transition from the closed forest up to the uppermost 2-m tall tree) will shift upwards in response to climate warming despite recent meta-analyses of worldwide treeline dynamics that do not support this statement (Harsch et al. 2009, 2014). Consequently, we need a better understanding on the causes of treeline formation if we aim to use treelines as surrogates of forests' response to global climate change.

Yet, there has been an ongoing debate during the past four decades on the exact causes of upper treeline formation, i.e. why they are located at certain elevations and which climatic factors determine the uppermost limit of tree existence (Smith et al. 2003; Körner 1998). Nowadays, treeline formation is attributed to the influence of a minimum threshold of soil temperatures on root growth (Körner 2012). This theory is based on the stronger control exerted by low temperature on carbon sinks (growth) than on sources (photosynthesis) as indicated by the accumulation of non-structural carbohydrates by trees as we approach the treeline (Fajardo et al. 2012). However, other factors considered to operate locally may also contribute to explain global patterns and affect temperature-limited upper and northern treelines such as the amount and duration of snow cover. Moreover, nowadays it is difficult to study purely climate-driven treelines since human impact is an additional disturbing factor in most regions (Treml et al. 2012). 
Temperature thresholds have also been proposed to explain abrupt changes in radial growth across the treeline ecotone (Paulsen et al. 2000). Radial growth enhancement has been observed in many treelines being mostly attributed to warmer temperatures (Rolland et al. 1998; Camarero and Gutiérrez 2004; Salzer et al. 2009). However, upward treeline shifts have not always accompanied this growth stimulation leading to a lag in treeline responses to climate (Camarero and Gutiérrez 2004; Kullman 2007). Nevertheless, radial growth remains as a consistent proxy of treeline responses to climate (Slatyer and Noble 1992).

At a global scale, seasonal root temperatures correlate with treeline elevation with some exceptions (Körner and Paulsen 2004). Mediterranean treelines illustrate one of these exceptions since they occur in places with-warmer temperatures than predicted by the worldwide distribution pattern. This has been explained by the lack of coldresistant treeline taxa or because of widespread human-depressed treelines due to past anthropogenic use (Körner 2012). Nevertheless, there is a general data gap on local climate data (e.g. soil temperatures) as related to radial-growth trends across Mediterranean treelines. Filling this gap could allow answering what drives the location of Mediterranean treelines beside low temperatures and possible drought as Fajardo et al. (2011) proposed.

Here, we explore these ideas by recording daily soil temperatures during three years in six Pyrenean treelines. Then, we analyze how growth and wood anatomy of trees at these sites respond to climate. Lastly, we place our findings in a wider context by investigating other treelines where growth is potentially limited by low temperatures and also by water shortage. Our aim is to understand the ultimate climatic drivers of tree growth at treeline with a particular emphasis on Mediterranean environments. We hypothesize that a combination of coldness and drought stress restrain growth in 
Pyrenean treelines depending on how prevailing are continental or maritime climatic conditions.

\section{Material and methods}

\section{Study sites and species}

Data were collected in six study sites forming relatively undisturbed treelines, i.e. lacking recent signs (stumps, charcoal) of human use (logging, grazing) across the Pyrenees (Table 1, Fig 1). This range is located between the Mediterranean Sea and the Atlantic Ocean, which leads to different temperature and rainfall regimes along latitudinal and longitudinal gradients. The extreme western part of the region falls under oceanic influence and it is characterized by high annual and winter-spring precipitations, usually falling as snow from December up to April, and relatively small differences between summer and winter temperature (Online Resource 1). This oceanic influence decreases eastwards and southwards where Mediterranean conditions prevail (e.g., warm-dry summer but wet autumn conditions eastwards). Most areas within the Central Pyrenees are mainly subjected to continental influences (Del Barrio et al. 1990).

Only mountain pine (Pinus uncinata Ram.) individuals established in $20^{\text {th }}$ century were sampled to test the growth responsiveness to climate of young and coetaneous trees grown under relatively warm conditions. This species constitutes the main component of the upper forest limits and treelines in the Spanish Pyrenees. Mountain pine is a shade-intolerant and frost-resistant species forming most of the tree ring from May to August (Camarero et al. 1998). As in most European mountains, Pyrenean treelines have been historically altered and shifted downwards due to human activities such as logging and grazing (Améztegui et al. 2010). However, the recent abandonment of traditional forest uses and climate warming has boosted the invasion of 
alpine grasslands by mountain pine and the establishment of young trees forming a climate-driven treeline (Camarero and Gutiérrez 2002, 2004).

\section{Long-term climate data}

The lack of long-term and high-quality climate records in mountain regions with complex topography also affects the Pyrenees due to the absence of meteorological stations located above $1500 \mathrm{~m}$ a.s.l. with a continuous record at least 30 years long. Therefore, we used the $0.5^{\circ}$-gridded CRU TS 3.0 data set produced by the Climate Research Unit, which was built using instrumental records from a network of meteorological stations over the global land surface and after subjecting those data to homogeneity tests and relative adjustments (Mitchell and Jones 2005). We are aware that these interpolated climate data do not fully represent the site conditions of treeline trees but this was the only reliable source of long-term climate data we could find. We considered the $0.5^{\circ}$ grid including each of the study sites and obtained monthly data (mean temperature, total precipitation) for the period from 1950 to 2008. Linear trends in standardized annual mean temperatures were calculated for the period 1950-2008 and compared with data from a high-elevation site representative of the central Pyrenees (Pic du Midi: 4304’N, 009’E, 2,862 m a.s.l., data for period 1950-1984; see Bücher and Dessens 1991). Since 1950, standardized annual temperatures significantly $(P<$ 0.001 ) rose at all study sites with mean rates in the range of to $+0.03^{\circ} \mathrm{yr}^{-1}$ (sites EY, $\mathrm{CN}$ ) to $+0.04^{\mathrm{o}} \mathrm{yr}^{-1}$ (rest of sites) (Online Resource 2). These warming trends were similar across the Pyrenean region since temperature rose similarly in all compared sites $(r=0.90-0.99, P<0.001)$. Further, despite these trends are based on gridded temperature data sets they match the trends observed in a high-elevation station during the period 1950-1984 in the case of nearby sites SO, AU and GE $(r=0.57, P<0.001)$. 
Note that the rise of air temperatures was most pronounced since the late 1980s and this explains why the warming trend observed at Pic du Midi data was not significant at the $5 \%$ probability level for the period $1950-1984(r=0.26, P=0.13)$. Lastly, no trend was observed for precipitation data considering the same period (see also Büntgen et al. 2008; Galván et al. 2014 for more details). Climatic data used in the pairs of sites SOAU and EY-CN were the same since these sites were included in the same $0.5^{\circ}$ grids.

\section{Estimation of root zone temperatures based on air temperatures}

The shallow-soil temperature (hereafter named soil or root-zone temperature following Körner and Paulsen, 2004) was measured at a 10-cm depth using Tidbit data loggers (Onset Co., Bourne, USA). One data logger was buried in each studied treeline ecotone in open areas, i.e. not under tree crowns, to characterize the root-zone temperatures (Körner and Paulsen 2004). Root-zone temperatures were measured with a 1-h temporal resolution from October 2005 to October 2008 (Table 1).

Following Körner (2012), we defined the growing season at treeline as the period during which the weekly mean air temperature is above $0{ }^{\circ} \mathrm{C}$. Since root-zone temperatures are buffered against extreme air thermal fluctuations, daily mean air temperatures of $0^{\circ} \mathrm{C}$ match daily mean root-zone temperatures of $3.5^{\circ} \mathrm{C}$ and the growing season can be considered the period including days with mean soil temperatures above $3.5^{\circ} \mathrm{C}$ (see Körner and Paulsen 2004).

To get a broader geographical view of soil thermal conditions at Pyrenean treelines we selected additional treeline positions obtained from previous regional studies (Camarero and Gutiérrez 2004; Batllori and Gutiérrez 2008) to estimate their air and soil temperatures. In total 12 treeline locations across the Pyrenees were considered (Fig 1) and monthly mean air temperatures were obtained for those sites from the 
Worldclim database (Hijmans et al. 2005). These monthly data were converted into mean daily air temperature by applying cubic splines. The temperature transfer model employed to convert daily air into soil or root-zone mean temperatures was created by using time-lagged regression techniques following Gehrig-Fasel et al. (2008). The model was fitted with data from the Sobrestivo (SO) site for the period with soil temperatures above $0^{\circ} \mathrm{C}$. We used the following equation:

$$
\begin{aligned}
& \operatorname{diff}\left(T r z_{\mathrm{d}}\right)=0.8176 * \operatorname{diff}\left(T a_{\mathrm{d}}\right)+0.1358 * \operatorname{diff}\left(T a_{\mathrm{d}-1}\right)+0.1203 * \operatorname{diff}\left(T a_{\mathrm{d}-2}\right)+0.0044 \\
& \text { where } \operatorname{Tr} z \text { is the mean soil root-zone temperature; } T a \text { is the mean air }
\end{aligned}
$$
temperature; d, d-1 and d-2 are the current, preceding and prior to the preceding days; and $\operatorname{diff}(x)$ are first- difference values used to remove the first-order autocorrelation of temperature data. A seven-day long running mean was used to smooth fluctuations in daily soil temperatures. We also removed seasonal trends from the input temperature data by subtracting fitted values obtained with a 0.9 -degree stiff loess (locally weighted polynomial regression) smoother. The model was successfully cross-validated using the other five study treeline sites with available soil temperature data (for all cases we obtained $r>0.90, P<0.001)$ We used this model to convert monthly mean air temperatures of additional treelines into root-zone soil temperatures and to calculate the duration and mean value of the growing season based on those data for the whole set of Pyrenean treeline data set.

\section{Tree growth}

We sampled dominant trees forming the treeline and showing similar size and age, i.e. they have been born between the late $19^{\text {th }}$ century and the early $20^{\text {th }}$ century. Tree size was measured (dbh, diameter at breast height measured at $1.3 \mathrm{~m}$ ). We took two cores per individual on opposite sides of the tree and perpendicular to the maximum slope 
using a Pressler increment borer. In total 95 cores from 48 trees (on average 8 trees per site) were collected in all study sites. For each site, the cores were prepared following dendrochronological methods (Fritts 2001). All samples were visually cross-dated and then measured to a precision of $0.01 \mathrm{~mm}$ using a Lintab measuring system (Frank Rinn, Heidelberg, Germany). Cross-dating was further statistically validated using the program Cofecha, which calculates moving correlations between individual series and a reference mean series or site chronology (Holmes, 1983). Since the sample replication was low in the first half of $20^{\text {th }}$ century, tree-ring width data were considered for the common period 1950-2008 in all sites excepting SO and EY.

To model growth trends as a function of climate we transformed tree-ring width series into annual basal area increment (hereafter abbreviated as BAI and expressed in $\mathrm{cm}^{2}$ year $^{-1}$ ) using the following formula:

$$
\mathrm{BAI}=\pi\left(r_{t}^{2}-r_{t-1}^{2}\right)
$$

where $r_{t}$ and $r_{t-1}$ are the radii corresponding to years $t$ and $t-1$, respectively. We used BAI because it is more biologically meaningful expression of growth than tree-ring widths or indices since BAI displays a young exponential phase and reaches an asymptotic phase when trees reach a mature stage (Biondi and Qaedan 2008).

In those cases when tree cores did not reach the pith, the distance to the theoretical center of the stem was estimated by fitting a template of concentric circles to the curve of the innermost rings (Norton et al. 1987). These geometric corrections were used to estimate the age at $1.3 \mathrm{~m}$ of all trees. We obtained BAI values for each core, which were then averaged for each tree and site for further analyses. The common interval 1950-2008 was considered for all sites excepting sites SO and EY where shorter intervals were used. To account for the effects of temporal autocorrelation in correlation analyses between air temperature and BAI, we estimated the corrected $95 \%$ confidence 
intervals for the correlation coefficients between both linearly detrended variables based on the autocorrelation of the original data (Mudelsee 2003).

\section{Analyses of wood anatomy}

The analysis of tracheid anatomical measurements was performed on four specific annual rings from a set of tree cores with the ring-width series that had the highest correlation with the mean chronology of the corresponding site, i.e. those trees that better represent the common growth of the stand. Years were selected on the basis of their spring thermal conditions, as spring and early summer temperature have been found the more important factor defining seasonal growth and tree ring structure: 1970 and 1984 displayed minimum values of mean spring temperature, whereas 2003 and 1997 displayed maximum values. Five series were selected in each of the four analyzed sites (AU, GE, CA, CN), with a total of 20 annual rings.

To perform cell anatomical surveys digital images of ring cross sections (RGB, color 24 bit) were captured using a digital video camera (Leica DFC 290) connected to a light microscope (Olympus BH2) with at 100X magnification. Since the attention was put in spring temperature just the first quarter of the ring was analyzed, i.e. the early earlywood. Adjacent images were taken for each ring, merged and then transformed into black and white using the program Adobe Photoshop version 10.0. For each selected ring, the tracheid lumen transversal width and double cell-wall thickness were measured along five tracheid files using the image analysis program ImageJ (Abramoff et al. 2004), which was used to discriminated between tracheid cell walls and cell lumen according to the variation of the grey value along a line passing through a tracheid radial file. Lumen transversal width and double cell-wall thickness means were obtained for year and site. 


\section{Statistical analyses of growth and wood anatomy}

Linear mixed-effects models were employed to evaluate the relationship between growth (BAI) and climate at each sampling location considering the common period 1950-2008 excepting in the case of sites SO and EY. Individual tree was designated as a random effect, while climate variables and dbh of trees were considered fixed effects using the following model:

$$
\ln \mathrm{BAI}_{i i}=\beta_{0}+\beta_{1} d b h_{i}+\beta_{2} \text { age }_{i}+\beta_{3} \text { climate }_{i j}+\varepsilon_{i j}
$$

where the BAI of a tree $i$ for year $j$ is a function of the model intercept $\left(\beta_{0}\right)$ and several parameters $\left(\beta_{0}\right.$ to $\left.\beta_{3}\right)$ adjusting the fixed tree (dbh, age) and climatic variables, and $\varepsilon_{i j}$ is the error term. Monthly mean temperature and total precipitation were considered from September of the year prior to tree-ring formation to September of the following year based on a previous study of xylogenesis in mountain pine (Camarero et al. 1998). In order to deal with temporal autocorrelation in BAI values, an autoregressive model of first order, which expresses the current BAI as a linear function of the previous year BAI, was included in the analysis (Pinheiro and Bates, 2000). Climate variables were standardized to enable direct comparison of coefficients from different climate factors. Variance inflated factors (VIF), which identify multi-collinearity in a matrix of predictor variables, were used to assess which explanatory variables are collinear and should be dropped to avoid redundant information (Fox and Monette 1992). We removed one variable at time, recalculated VIF and repeated this process until all VIF values were smaller than 2.5 to find a set of non-redundant variables. Model selection was based on the second-order Akaike Information Criterion (AICc) and all models that differed less than 2 points with the lowest AICc value were averaged to obtain modelaveraged coefficients and probabilities (Burnham and Anderson 2002). Linear mixed- 
effects models were used to further test for differences in tracheid lumen transversal widths and double cell wall thickness. Site and year, as well as the interaction between them, were considered as explanatory variables or fixed factors. Individual tree was designated as a random effect to account for non-independence of data from the same individual (Zuur et al. 2009). Differences between years in wood anatomical variables were evaluated using the post-hoc Student-Newman-Keuls (SNK) test. The model selection for the linear mixed-effects models was done using the nlme (Pinheiro et al. 2013) and MuMIn (Barton 2013) packages, respectively, in the R statistical software (R development Core Team 2012).

\section{Treeline comparison}

To compare our findings with similar treelines from transitional mid-latitude areas subjected to both temperature and potentially water constrains on growth we selected two sites (Aktasch, Russia; Larix sibirica Ledeb., 50.25 N, 87.35 W, 2000 m a.s.l.; Sarejmek, Kyrgyzstan, Picea shrenkiana Fish \& C.A.Mey, 41.36 N, 75.09 W, 2800 m a.s.1.) where tree-ring data (width, maximum and minimum wood densities) were available for at least 15 trees (30-40 radii) and covered the period 1900-1993. Indexed mean series (chronologies) of tree-ring width, minimum and maximum wood densities were obtained for those two sites from the International Tree Ring Data Bank (ITRDB, http://www.ncdc.noaa.gov/data-access/paleoclimatology-data/datasets/tree-ring; sites correspond to ITRDB codes russ135 and russ152). The elevation of these sites was less than $100 \mathrm{~m}$ below the theoretical treeline elevation for their latitude based on global observed patterns (Körner 2012). The indices of tree-ring variables were correlated with monthly climate data of the CRU TS 3.0 data set (mean minimum and maximum air 
temperatures, total precipitation) from the previous October up to the current September.

\section{Results}

The mean duration of the growing season, averaged over all six sites (Table 1), was 177 days, and it was especially short in EY (139 days) as compared with the rest of sites (Fig 2). The mean starting (17 May) and ending (9 November) dates of the growing season did not differ significantly among 2006 and 2007 (results not presented). The mean root-zone temperature measured at all treeline sites during the growing season was $8.2 \pm 0.2^{\circ} \mathrm{C}$. However, this regional average value was uneven with the largest differences $\left(1.8^{\circ} \mathrm{C}\right)$ found between nearby sites EY and $\mathrm{CN}$ (Table 1). These two easternmost sites presented the highest percentages of negative soil-temperatures recordings, most likely because of the smallest and shortest snow cover (EY, 47\%; CN, $37 \%$ ) followed by the rest of sites (SO, 26\%; AU, 23\%; GE, 24\%; CA, 28\%). The use of Worldclim data produced an estimated root-zone temperature during the growing season of $7.5 \pm 0.2^{\circ} \mathrm{C}$.

We found highly significant correlations between soil and air temperatures recorded near site $\mathrm{SO}\left(\mathrm{R}^{2}=0.42, P<0.05\right)$ thus validating the transfer model. The paired correlations of mean BAI series between sites were significantly and negatively related to differences in mean soil temperature during the growing season $(r=-0.63, P$ $=0.01$ ), i.e. the lower the differences in soil temperatures were between sites, the more similar the site BAI series were (Fig 3).

Linear mixed-effects models revealed a significant influence of climate variables on growth (Table 2, Fig 4). Previous November and current May temperature and July precipitation were the main climate variables driving mountain pine growth in Pyrenean 
treelines. For instance, warmer May conditions were the main climatic driver enhancing growth in four out of the six study treelines. But, wet July conditions favoured growth in one of the eastern sites (site EY), whereas warmer spring and summer temperatures did it in the other eastern site (site $\mathrm{CN}$ ). Therefore, climate conditions are not equally controlling mountain pine growth across Pyrenean treelines.

Regarding wood-anatomical data, both the lumen transversal width $(F=23.79$, $P<0.001)$ and the double cell-wall thickness $(F=17.63, P<0.001)$ differed significantly among sites. However, only the lumen width of earlywood tracheids differed $(F=4.57, P=0.03)$ among years. In all four compared sites, the colder the spring temperatures the narrower the lumens (Fig 5).

Finally, warm late-spring to summer conditions enhanced growth and wood density indices at the two compared treelines located outside the Pyrenees (Fig 6). In the case of maximum wood density these positive correlations were the highest for late summer temperatures, whilst in the case of minimum wood density we detected in both sites significant but negative association with spring and summer precipitations during the growing season. In one of these sites, the maximum wood density was also negatively related to summer precipitation.

\section{Discussion}

We describe complex climate restrictions of growth and upper treeline formation in the Pyrenees, and also in transitional mid-latitude treelines located between semi-arid and temperate biomes. Temperature in the early growing season is the main driver of radial growth at treelines where water balance is highest, i.e. central and western Pyrenees in the study case. Indeed, sites showing more similar soil temperatures present more similar long-term growth trends. This suggests that air temperature synchronizes 
treeline growth at regional scales via local changes in soil root-zone temperatures. But, water availability also influences growth in sites subjected to drier conditions (e.g. the eastern Pyrenees) as we also observed in the other mid-latitude treelines.

Air temperatures are expected to rise significantly in the forthcoming decades across most mountainous regions of the world (IPCC 2013), but there is a great uncertainty on how local factors (e.g. elevation, aspect, soil) would modulate how trees at treeline perceive that global warming. A warmer climate could differentially affect treeline dynamics as a function of diverse bio-geographical patterns of tree growth response to climate as those here portrayed for the Pyrenees. Predicted warmer spring and autumn conditions across the Pyrenees (López-Moreno et al. 2008) should enhance long-term growth trends of Pyrenean mountain pine treelines if they do not lead to drier conditions, i.e. if evaporative demand does not outpace water availability. At the same time, such trends could result in a mismatch between plant phenology and snow cover fluctuations through a rapid snow melting in late winter.

Air temperatures above $5{ }^{\circ} \mathrm{C}$ are required for enabling tissue development in treeline areas with unfrozen soils according to the growth-limitation hypothesis (Körner 2012). But in many mountain regions, how climate drives vegetation patterns is unknown due to the lack of reliable microclimatic data showing actual life conditions (Kollas et al. 2014). We detected that an extrapolation based on coarse-scale or gridded climatic data sets (e.g. Worldclim, CRU, etc.) underestimated by $-0.7^{\circ} \mathrm{C}$ the actual root-zone soil temperature at treeline measured in the field. We also detected negative soil temperatures in the study sites, occurring right before or after the period of permanent snow cover, when autumnal-winter and winter-springtime soil temperatures suddenly drop and soils are still not covered by snow. In the study sites, negative soil temperatures were most frequent in the Mediterranean sites (e.g. site EY) and 
particularly during winter, indicating scarce snow cover together with melting and/or wind-blow conditions. Those winter conditions can also contribute to drought stress later in spring and negatively affect treelines (Crimmins et al. 2011).

We estimated a similar duration (177 days) and timing (mid May to early November) of the growing season across Pyrenean mountain pine treelines based on detailed recordings of root-zone soil temperatures (Fig 2), but we also detected local divergences such as a shorter duration in Mediterranean sites. Growing-season temperatures are the main driver of growth at Pyrenean treelines excepting in the easternmost sites subjected to more Mediterranean influence including a higher water deficit during the growing season in spring and summer (Table 2). These patterns match previous studies because most mountain pine growth processes (shoot and needle elongation, tree-ring thickening and lignification) occur from May to October (Guerrero-Campo et al. 1998) and its radial growth is favoured by warmer May and June conditions (Gutiérrez, 1991; Tardif et al. 2003; Büntgen et al. 2008, 2010; Galván et al. 2014). This implies that warm conditions early in the growing season may advance cambial onset and determine the maximum growth rates, and possibly most of the final tree-ring width (Kirdyanov et al. 2003; Moser et al. 2010), justifying the asymmetry of xylogenesis in this species, i.e. growth rates are much faster in the early (May-August) than in the late (September-November) growing season (Camarero et al. 1998). A threshold root-zone temperature triggers the spring onset of cambial activity at the treeline, which is probably a lagged response to previous increases in air temperature (Rossi et al. 2007; Gruber et al. 2009). Warm temperatures at the end of the growing season (November) do not directly influence radial growth but could enhance the synthesis of carbohydrates mostly allocated for earlywood formation the following year (Felten von et al. 2007). 
Warm conditions in early spring also enhance tracheid enlargement rates (Vaganov et al. 2006), and they influenced the lumen area of earlywood tracheids in mountain pine treelines, but not cell-wall thickness (Fig 5). Warmer spring conditions should therefore increase the hydraulic conductivity provided by earlywood tracheids, which accounts for most of the total conductivity of the ring (Hacke et al. 2001). If wider earlywood tracheids are formed in response to warmer temperatures, this could also increase their risk of cavitation if water shortage occurs in early spring (Cochard 1992). Extreme water deficit could also lead to a reduced radial enlargement of tracheids (Hsiao and Acevedo 1974). Despite the existence of drought stress in some treelines is still a controversial issue (Körner 2012), the fact that growth of some mountain pine treelines responds to spring and summer precipitation confirm this idea for the eastern Pyrenees (Table 2). Moreover, the negative associations observed between minimum wood density and growing-season precipitation at treelines located between dry and temperate biomes confirms this fact for other transitional mid-latitude areas (Fig 6). Higher values of minimum wood density were related to drier spring conditions, because a drought-induced reduction in the radial expansion of tracheids increases earlywood density (Camarero et al. 2014).

Our findings suggest a new way to distinguish local from global treeline drivers. Warmer but drier conditions could lead to a reduced growth of transitional mid-latitude treelines subjected to certain drought stress as those studied in the eastern Pyrenees. We consider that such drought stress is caused by the stronger Mediterranean influence on the eastern than on the western and central Pyrenees despite we can not discard that local factors (topography, soil type, canopy cover) could also affect growth at treeline. We based our approach on the direct measurement of growth and climatic data. This assessment should be compared with surrogates evidencing temperature limitations of 
growth at treeline such as the analyses of the concentration of non-structural carbohydrates and carbon isotope ratios, respective proxies of carbon use and water use efficiency. For example, Fajardo et al. (2011) used those proxies and inferred that growth and carbon gain in a Nothofagus pumilio Mediterranean treeline may be more controlled by water shortage than by low temperatures. As they suggested, we need a more comprehensive treeline theory based on the carbon limitation imposed by climatic constrains which includes Mediterranean-type treelines, irrespective of local (e.g. past human use in the Pyrenees; cf. Améztegui et al. 2010) and taxonomic considerations (e.g. lack of cold-resistant tree species in the southern Hemisphere; cf. Körner 2012). Overall, our findings indicate that including drought as a limiting factor of growth, i.e. carbon and nutrients use by meristems, could explain the biogeographical zonation of Mediterranean treelines. Nevertheless, there are few mountain systems in the Mediterranean that are large and high enough to form temperature-driven and not biased (via summit or human-use effects) treeline. The picture is changing as we move to Central Asia or South America so our ideas could also be tested in large ranges located there (Himalaya, Andes).

We contribute additional evidence showing that drought plays a role as growth constraint not only in areas with pronounced water deficit but also in specific treelines as has been also observed in boreal (Aakala and Kuuluvainen 2011), mountain (Oberhuber 2001) and temperate forests (Pederson et al. 2014). In the aforementioned cases the effect of drought stress on growth was due to low soil moisture availability induced by warm summer temperatures, which indicates that local factors such as soil depth and stoniness or slope steepness may lead to drought stress in cold climate treelines (Villalba et al. 1994; Galván et al. 2014). In many cases local factors override climatic factors as drivers of growth in mountain environments (Bunn et al. 2005; Treml 
et al. 2012). Furthermore, precipitation may be more important driver of growth than temperatures at treeline under subtropical (Morales et al. 2004), Mediterranean (Lloyd and Graumlich 1997) and continental (Kress et al. 2010; Liang et al. 2014; Yu et al. 2014) conditions. This also has bio-geographical implications since constrains on tree growth due to warming-related drought stress may nullify any beneficial effect on treelines due to the rising temperatures.

\section{Acknowledgments}

E. González de Andrés acknowledges the support of a FPI fellowship (Economy and Innovation Ministry, Spain). We sincerely thank Jeff Diez for revising a draft of the manuscript. 


\section{References}

Aakala T, Kuuluvainen, T (2011) Summer droughts depress radial growth of Picea abies in pristine taiga of the Arkhangelsk province, northwestern Russia. Dendrochronologia 29:67-75.

Abramoff MD, Magalhaes PJ, Ram SJ (2004) Image processing with ImageJ. Biophotonics International 11:36-42.

Améztegui A, Brotons Ll., Coll Ll (2010) Land-use changes as major drivers of mountain pine (Pinus uncinata Ram.) expansion in the Pyrenees. Global Ecol Biogeogr 19: 632-641.

Arno SB (1984) Timberline: Mountain and Arctic Forest Frontiers. The Mountaineers, Seattle, USA.

Barton K (2013) MuMIn: Multi-model inference. http://cran.r-project.org/ web/packages/MuMIn/MuMIn.pdf. Accessed 14 June 2013.

Batllori E, Gutiérrez E (2008) Regional tree line dynamics in response to global change in the Pyrenees. J Ecol 96:1275-1288.

Biondi F, Qaedan F (2008) A theory-driven approach to tree-ring standardization: Defining the biological trend from expected basal area increment. Tree-Ring Res 64:81-96.

Bücher A, Dessens J (1991) Secular trend of surface temperature at an elevated observatory in the Pyrenees. J Climate 4:859-868.

Büntgen U, Frank DC, Grudd H, Esper J (2008) Long-term summer temperature variations in the Pyrenees. Clim Dynam 31:615-631.

Büntgen U, Frank D, Trouet V, Esper J (2010) Diverse climate sensitivity of Mediterranean tree-ring width and density. Trees-Struct Funct 24:261-273. 
Bunn AG, Waggoner LA, Graumlich LJ (2005) Topographic mediation of growth in high elevation foxtail pine (Pinus balfouriana Grev. et Balf.) forests in the Sierra Nevada, USA. Global Ecol Biogeogr 14:103-114.

Burnham KP, Anderson DR (2002) Model Selection and Multimodel Inference. Springer, New York.

Camarero JJ, Gutiérrez E (2002) Plant species distribution across two contrasting treeline ecotones in the Spanish Pyrenees. Plant Ecol 162:247-257.

Camarero JJ, Gutiérrez E (2004) Pace and pattern of recent treeline dynamics: response of ecotones to climatic variability in the Spanish Pyrenees. Climatic Change 63:181-200.

Camarero JJ, Guerrero-Campo J, Gutiérrez E (1998) Tree-ring growth and structure of Pinus uncinata and Pinus sylvestris in the Central Spanish Pyrenees. Arctic Alpine Res 30:1-10.

Camarero JJ, Rozas V, Olano JM (2014) Minimum wood density of Juniperus thurifera is a robust proxy of spring water availability in a continental Mediterranean climate. J Biogeogr 41:1105-1114.

Cochard H (1992) Vulnerability of several conifers to air embolism. Tree Physiol $11: 73-83$.

Crimmins SM, Dobrowski SZ, Greenberg JA, Abatzoglou JT, Mynsberge AR (2010) Changes in climatic water balance drive downhill shifts in plant species' optimum elevations. Science 21:324-327

Del Barrio G, Creus J, Puigdefábregas J. (1990) Thermal seasonality of the high mountain belts of the Pyrenees. Mt Res Dev 10:227-233. 
Fajardo A, Piper FL, Cavieres LA (2011) Distinguishing local from global climate influences in the variation of carbon status with altitude in a tree line species. Global Ecol Biogeogr 20:307-318.

Fajardo A, Piper FI, Pfund L, Körner C, Hoch G (2012) Variation of mobile carbon reserves in trees at the alpine treeline ecotone is under environmental control. New Phytologist 195:794-802.

Felten von S, Hättenschwiler S, Saurer M, Siegwolf R (2007) Carbon allocation in shoots of alpine treeline conifers in a $\mathrm{CO}_{2}$ enriched environment. Trees-Struct Funct 21:283-294.

Fox J, Monette G (1992) Generalized collinearity diagnostics. J Am Stat Assoc 87:178183.

Fritts HC (2001) Tree Rings and Climate. Blackburn Press, Caldwell, NJ, USA.

Galván D, Camarero JJ, Gutiérrez E (2014) Seeing the trees for the forest: drivers of individual growth responses to climate in Pinus uncinata mountain forests. J Ecol 102:1244-1257.

Gehrig-Fasel J, Guisan A, Zimmermann NE (2008) Evaluating thermal treeline indicators based on air and soil temperature using an air-to-soil temperature transfer model. Ecol Model 213:345-355.

Gruber A, Baumgartner D, Zimmermann J, Oberhuber W (2009) Temporal dynamic of wood formation in Pinus cembra along the alpine treeline ecotone and the effect of climate variables. Trees-Struct Funct 23:623-635.

Guerrero-Campo J, Camarero JJ, Gutiérrez E (1998) Crecimiento estacional y caída de acículas en Pinus uncinata Ram. y Pinus sylvestris L. Inv. Agraria: Sistemas y Recursos Forestales 7:155-172. 
Gutiérrez E (1991) Climate tree-growth relationships for Pinus uncinata Ram. in the Spanish pre-Pyrenees. Acta Oecol 12:213-225.

Hacke UG, Sperry JS, Pockman WT, Davis SD, McCulloh KA (2001) Trends in wood density and structure are linked to prevention of xylem implosion by negative pressure. Oecologia 126:457-461.

Hagedorn F, Shiyatov FG, Mazepa VS, Devi NM, Grygoriev AA, Bartyish AA, Fomin V, Kapralov D, Terentiev M, Bugman H, Rigling A, Moiseev PA (2014) Treeline advances along the Urals mountain range - driven by improved winter conditions? Glob Change Biol 20:3530-3543.

Harsch MA, Hulme PE, McGlone MS, Duncan RP (2009) Are treelines advancing? A global meta-analysis of treeline response to climate warming. Ecol Lett 12:10401049.

Hijmans RJ, Cameron SE, Parra JL, Jones PG, Jarvis A (2005) Very high resolution interpolated climate surfaces for global land areas. Int J Climatol 25:1965-1978.

Holmes RL (1983) Computer-assisted quality control in tree-ring dating and measurement. Tree-Ring Bull 43:69-78.

Holtmeier FK, Broll G (2005) Sensitivity and response of northern hemisphere altitudinal and polar treelines to environmental change at landscape and local scales. Global Ecol Biogeogr 14:395-410.

Hsiao TC, Acevedo E (1974) Plant responses to water deficits, water use efficiency, and drought resistance. Agric Meteorol 14:59-84.

IPCC (2013) Summary for Policymakers. In: Stocker TF, Qin D, Plattner GK, Tignor M, Allen SK, Boschung J, Nauels A, Xia Y, Bex V, Midgley PM (eds.) Climate Change 2013: The Physical Science Basis. Contribution of Working Group I to the 
Fifth Assessment Report of the Intergovernmental Panel on Climate Change. Cambridge University Press, Cambridge, UK, pp 3-32.

Kirdyanov A, Hughes M, Vaganov E, Schweingruber F, Silkin P (2003) The importance of early summer temperature and date of snow melt for tree growth in the Siberian Subarctic. Trees-Struct Funct 17:61-69.

Kollas Ch, Randin CF, Vitasse Y, Körner C (2014) How accurately can minimum temperatures at the cold limits of tree species be extrapolated from weather station data? Agric For Meteorol 184:257-266.

Körner C, Paulsen J (2004) A world-wide study of high altitude treeline temperatures. J Biogeogr 31:713-732.

Körner C (1998) A re-assessment of high elevation treeline positions and their explanation. Oecologia 115:445-459.

Körner C (2012) Alpine Treelines. Springer, Basel.

Kress A, Saurer M,. Siegwolf RTW, Frank DC, Esper J, Bugmann H (2010) A 350 year drought reconstruction from Alpine tree ring stable isotopes. Global Biogeochem Cy 24:GB2011.

Kullman L (2007) Treeline population monitoring of Pinus sylvestris in the Swedish Scandes, 1973-2005: Implications for tree line theory and climate change ecology. J Ecol 95:41-52.

Liang E, Dawadi B, Pederson N, Eckstein D (2014) Is the growth of birch at the upper timberline in the Himalayas limited by moisture or by temperature? Ecology 95:2453-2465.

Lloyd AH, Graumlich L (1997) Holocene dynamics of treeline forests in the Sierra Nevada. Ecology 78:1199-1210. 
López-Moreno JI, Goyette S, Beniston M (2008) Climate change prediction over complex areas: spatial variability of uncertainties and predictions over the Pyrenees from a set of regional climate models. Int J Climatol 28:1535-1550.

Mitchell TD, Jones PD (2005) An improved method of constructing a database of monthly climate observations and associated high resolution grids. Int $\mathrm{J}$ Climatol 25:693-712.

Morales MS, Villalba R, Grau HR, Paolini L (2004) Rainfall-controlled tree growth in high-elevational subtropical treelines. Ecology 85:3080-3089.

Moser L, Fonti P, Büntgen U, Esper J, Luterbacher J, Franzen J, Frank D (2010) Timing and duration of European larch growing season along altitudinal gradients in the Swiss Alps. Tree Physiol 30:225-233.

Mudelsee M (2003) Estimating Pearson's correlation coefficient with bootstrap confidence interval from serial dependent time series. Math Geol 35:651-665.

Norton DA, Palmer JG, Ogden J (1987) Dendroecological studies in New Zealand 1. An evaluation of tree estimates based on increment cores. New Zea J Bot 25:373383.

Oberhuber W (2001) The role of climate in the mortality of Scots pine (Pinus sylvestris L.) exposed to soil dryness. Dendrochronologia 19:45-55.

Paulsen J, Körner C (2014) A climate-based model to predict potential treeline position around the globe. Alpine Bot 124:1-12

Paulsen J, Weber UM, Körner C (2000) Tree growth near treeline: abrupt or gradual reduction with altitude? Arct Antarct Alp Res 32:14-20.

Pederson N, Dyer JM, McEwan RW, Hessl AE, Mock CJ, Orwig DA, Rieder HE, Cook BI (2014) The legacy of episodic climatic events in shaping temperate, broadleaf forests. Ecol Monogr 84:599-620. 
Pinheiro JC, Bates DM (2000) Mixed-Effects Models in S and S-plus. Springer, New York.

Pinheiro JC, Bates D, DebRoy S, Sarkar D (2013) Linnear and nonlinear mixed effects models. $\mathrm{R}$ package version 3.1-113. http://CRAN.R-project.org/package=nlme. Accessed 13 June 2013.

R Development Core Team (2012) R: A Language and Environment for Statistical Computing. $\mathrm{R}$ Foundation for Statistical Computing, Vienna, Austria. http://www.R-project.org.

Rolland C, Petitcolas V, Michalet R (1998) Changes in radial tree growth for Picea abies, Larix decidua, Pinus cembra and Pinus uncinata near the alpine timberline since 1750. Trees-Struct Funct 13:40-53.

Rossi S, Desauriers A, Anfodillo T, Carraco V (2007) Evidence of threshold temperatures for xylogenesis in conifers at high altitudes. Oecologia 152:1-12.

Salzer MW, Hughes MK, Bunn AG, Kipfmueller KF (2009) Recent unprecedented treering growth in bristlecone pine at the highest elevations and possible causes. Proc Natl Acad Sci U S A 106:20348-20353.

Shiyatov SG (2003) Rates of change in the upper treeline ecotone in the Polar Ural Mountains. PAGES News 11:8-10.

Slatyer R O, Noble, I R (1992) Dynamics of montane treelines. In Hansen AJ, Di Castri F (eds) Landscape Boundaries, Consequences for Biotic Diversity and Ecological Flows. Springer-Verlag, New York, pp 327-345.

Smith WK, Germino MJ, Hancock TE, Johnson DM (2003) Another perspective on altitudinal limits of alpine timberlines. Tree Physiol 23:1101-1112. 
Tardif J, Camarero JJ, Ribas M, Gutiérrez E (2003) Spatiotemporal variability in tree growth in the Central Pyrenees: climatic and site influences. Ecol Monogr 73:241257.

Treml V, Ponocná T, Büntgen U (2012) Growth trends and temperature responses of treeline Norway spruce in the Czech-Polish Sudetes Mountains. Clim Res 55:91103.

Vaganov EA, Hughes MK, Shashkin AV (2006) Growth Dynamics of Conifer Tree Rings. Springer, Heidelberg, Germany.

Villalba R, Veblen TT, Ogden J (1994). Climatic influences on the growth of subalpine trees in the Colorado Front Range. Ecology 75:1450-1462.

Yu D, Wang Q, Liu J, Zhou W, Qi L, Wang X, Zhou L, Dai L (2014) Formation mechanisms of the alpine Erman's birch (Betula ermanii) treeline on Changbai Mountain in Northeast China. Trees-Struct Funct 28:935-947.

Zuur A, Ieno EN, Elphick CS (2009) A protocol for data exploration to avoid common statistical problems. Methods Ecol Evol 1:3-14. 


\section{Tables}

Table 1. Topographic, geological and climatic features characterizing the treeline study sites (mean \pm SE values). Root zone temperatures were measured in the field from October 2005 to October 2008. Underlined codes indicate sites for which wood-anatomical data are available.

\begin{tabular}{|c|c|c|c|c|c|c|c|c|c|c|}
\hline \multirow{2}{*}{ Site (code) } & \multirow{2}{*}{$\begin{array}{l}\text { Latitude } \\
\text { (N) }\end{array}$} & \multirow{2}{*}{$\begin{array}{l}\text { Longitude } \\
\text { (E) }\end{array}$} & \multirow{2}{*}{$\begin{array}{l}\text { Altitude } \\
\text { (m.a.s.1.) }\end{array}$} & \multirow{2}{*}{ Aspect } & \multirow{2}{*}{ Substrate } & \multirow{2}{*}{$\operatorname{Dbh}(\mathrm{cm})$} & \multirow{2}{*}{$\begin{array}{c}\text { Age at } \\
1.3 \mathrm{~m} \\
\text { (years) }\end{array}$} & \multirow{2}{*}{$\begin{array}{c}\text { Growing } \\
\text { season root } \\
\text { zone } \\
\text { temperature } \\
\left({ }^{\circ} \mathrm{C}\right)\end{array}$} & \multicolumn{2}{|c|}{$\begin{array}{l}\text { Period with root-zone temperatures } \\
\text { above }+3.5^{\circ} \mathrm{C}\end{array}$} \\
\hline & & & & & & & & & 2006 & 2007 \\
\hline $\begin{array}{l}\text { Sobrestivo } \\
(\mathrm{SO})\end{array}$ & $42^{\circ} 41^{\prime}$ & $0^{\circ} 05^{\prime}$ & 2350 & $\mathrm{~N}$ & limestone & $13.8 \pm 2.5$ & $55 \pm 7$ & $8.35 \pm 0.20$ & $\begin{array}{l}5 \text { May }-21 \\
\text { November }\end{array}$ & $\begin{array}{l}8 \text { May }-13 \\
\text { November }\end{array}$ \\
\hline $\begin{array}{l}\text { Lac d'Aumer } \\
(\underline{\mathrm{AU}})\end{array}$ & $42^{\circ} 50^{\prime}$ & $0^{\circ} 08^{\prime}$ & 2360 & $\mathrm{~S}$ & gneiss & $23.6 \pm 3.0$ & $92 \pm 17$ & $7.60 \pm 0.16$ & $\begin{array}{l}13 \text { May }-21 \\
\text { November }\end{array}$ & $\begin{array}{l}19 \text { May -13 } \\
\text { November }\end{array}$ \\
\hline Gerber ( $\underline{\mathrm{GE}})$ & $42^{\circ} 37^{\prime}$ & $0^{\circ} 59^{\prime}$ & 2380 & N-NW & gneiss & $22.6 \pm 3.1$ & $99 \pm 15$ & $8.63 \pm 0.19$ & $\begin{array}{l}12 \text { May }-21 \\
\text { November }\end{array}$ & $\begin{array}{l}19 \text { May -9 } \\
\text { November }\end{array}$ \\
\hline $\begin{array}{l}\text { Port de Cabus } \\
(\underline{\mathrm{CA}})\end{array}$ & $42^{\circ} 32^{\prime}$ & $1^{\circ} 24^{\prime}$ & 2420 & $\mathrm{~W}$ & schist & $22.0 \pm 3.2$ & $63 \pm 20$ & $8.28 \pm 0.20$ & $\begin{array}{l}16 \text { May }-16 \\
\text { November }\end{array}$ & $\begin{array}{l}19 \text { May }-9 \\
\text { November }\end{array}$ \\
\hline Eyne (EY) & $42^{\circ} 27^{\prime}$ & $2^{\circ} 06^{\prime}$ & 2400 & $\mathrm{~N}$ & gneiss & $33.4 \pm 3.3$ & $54 \pm 6$ & $7.35 \pm 0.14$ & $\begin{array}{l}7 \text { June }-4 \\
\text { November }\end{array}$ & $\begin{array}{l}13 \text { June }-19 \\
\text { October }\end{array}$ \\
\hline Canigò ( $\underline{\mathrm{CN}})$ & $42^{\circ} 29^{\prime}$ & $2^{\circ} 25^{\prime}$ & 2320 & W-NW & gneiss & $27.6 \pm 2.0$ & $63 \pm 5$ & $9.14 \pm 0.28$ & $\begin{array}{l}2 \text { May }-11 \\
\text { November }\end{array}$ & $\begin{array}{l}9 \text { May }-18 \\
\text { October }\end{array}$ \\
\hline
\end{tabular}


Table 2. Statistical parameters of linear mixed models adjusted to BAI (period 1950-2008 for all sites excepting SO and EY) and based on monthly estimated root zone temperatures (T) (monthly temperature transfer model, see equation 1) and monthly precipitation sums (P) for the six study locations. Subscripts indicate climate variables from previous (t-1) and current ( $\mathrm{t}$ ) year, respectively. Diameter at breast height (dbh) and age were also included as explanatory variables in the models. Variable combinations that differ $<2$ of Akaike Information Criterion (AIC) were averaged. Only coefficients from significant variables are shown, the highest coefficients in each site are highlighted in bold.

\begin{tabular}{lccccccccc}
\hline Site & dbh & \multicolumn{3}{c}{ Temperature } & \multicolumn{5}{c}{ Precipitation } \\
& & November $_{\mathrm{t}-1}$ & May $_{\mathrm{t}}$ & June $_{\mathrm{t}}$ & July $_{\mathrm{t}}$ & November $_{\mathrm{t}-1}$ & May $_{\mathrm{t}}$ & $\mathrm{June}_{\mathrm{t}}$ & July $_{\mathrm{t}}$ \\
\hline SO & 0.033 & $\mathbf{0 . 2 6 1}$ & 0.117 & & & 0.148 & & 0.109 & \\
AU & 0.026 & 0.217 & $\mathbf{0 . 3 8 9}$ & & & & & \\
GE & 0.036 & 0.103 & $\mathbf{0 . 3 2 1}$ & & & & & \\
CA & 0.046 & & $\mathbf{0 . 2 8 2}$ & 0.207 & & & & \\
EY & 0.025 & 0.150 & & & & & & \\
CN & 0.047 & 0.186 & $\mathbf{0 . 2 5 5}$ & 0.157 & 0.172 & & & \\
\hline
\end{tabular}




\section{Figures}
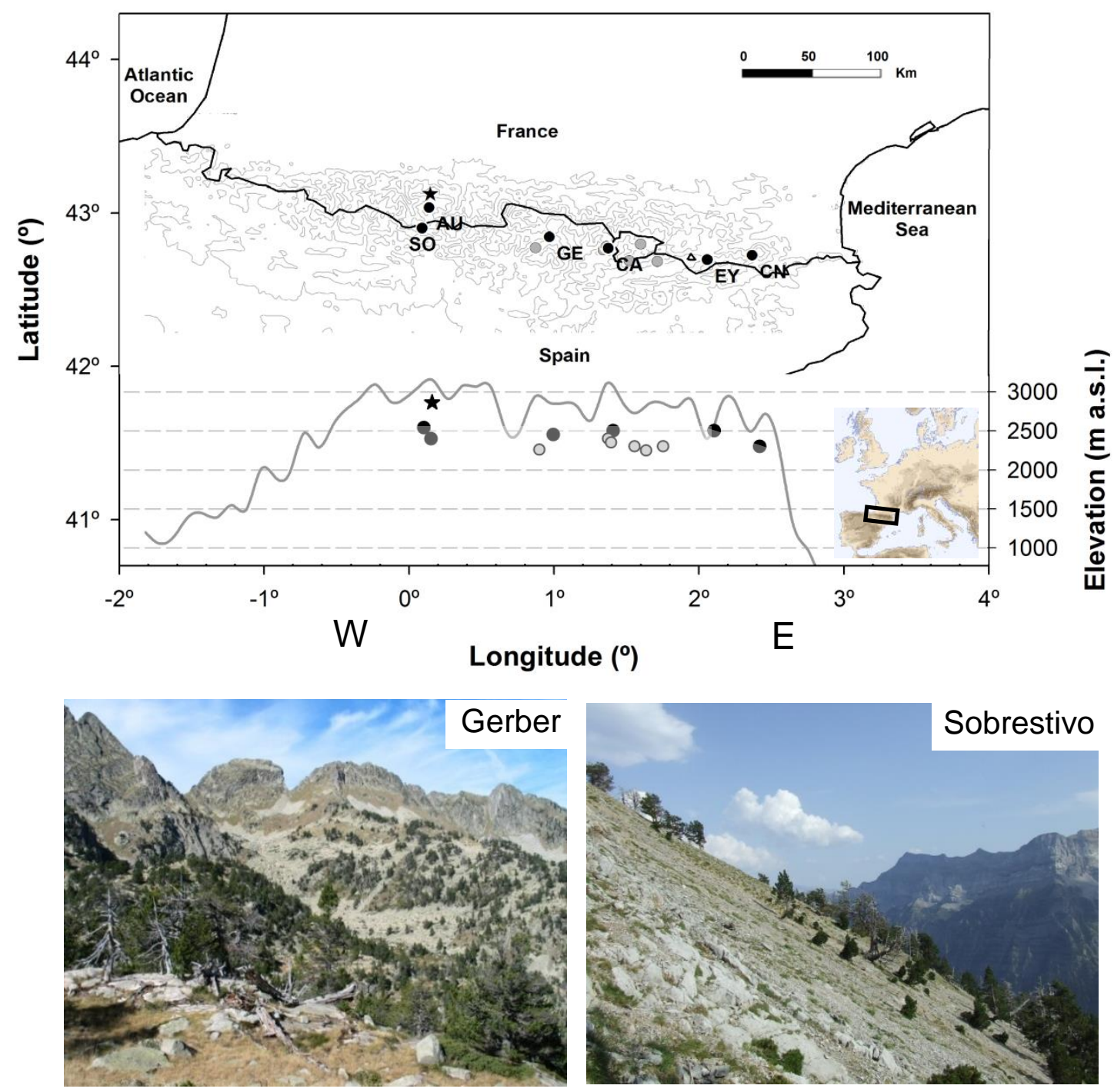

Figure 1 Geographical and topographical features of the six Pyrenean study treelines

(black spots, see sites' codes in Table 1) and the extra set of treeline locations (gray spots; see more details in Batllori and Gutiérrez 2008; Camarero and Gutiérrez 2004). The star indicates the location of the high-elevation Pic du Midi meteorological station. The grey areas show the theoretical Pyrenean treeline elevation. The lower right inset shows the location of the Pyrenees in Europe. The lower photographs illustrate the physiognomy of Pyrenean $P$. uncinata treelines located in Gerber and Sobrestivo study sites 


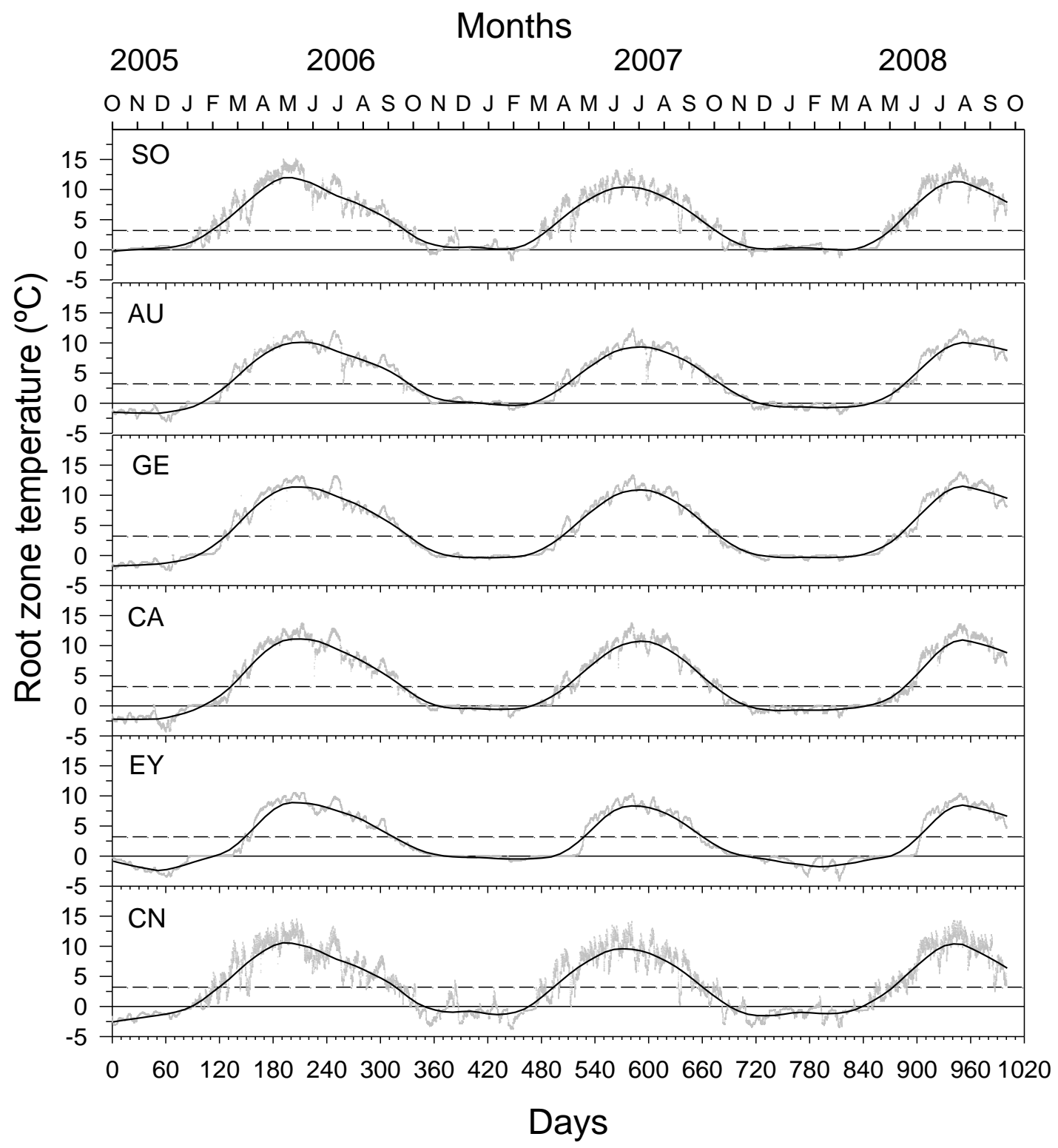

Figure 2 Daily means of root-zone temperature for each study site registered from October 2005 up to October 2008 at six Pyrenean treelines. Dashed horizontal lines indicate the threshold of $+3.5^{\circ} \mathrm{C}$ corresponding to the growing season. Smoothed lines show interpolated temperatures based on $10 \%$-long loess functions. 


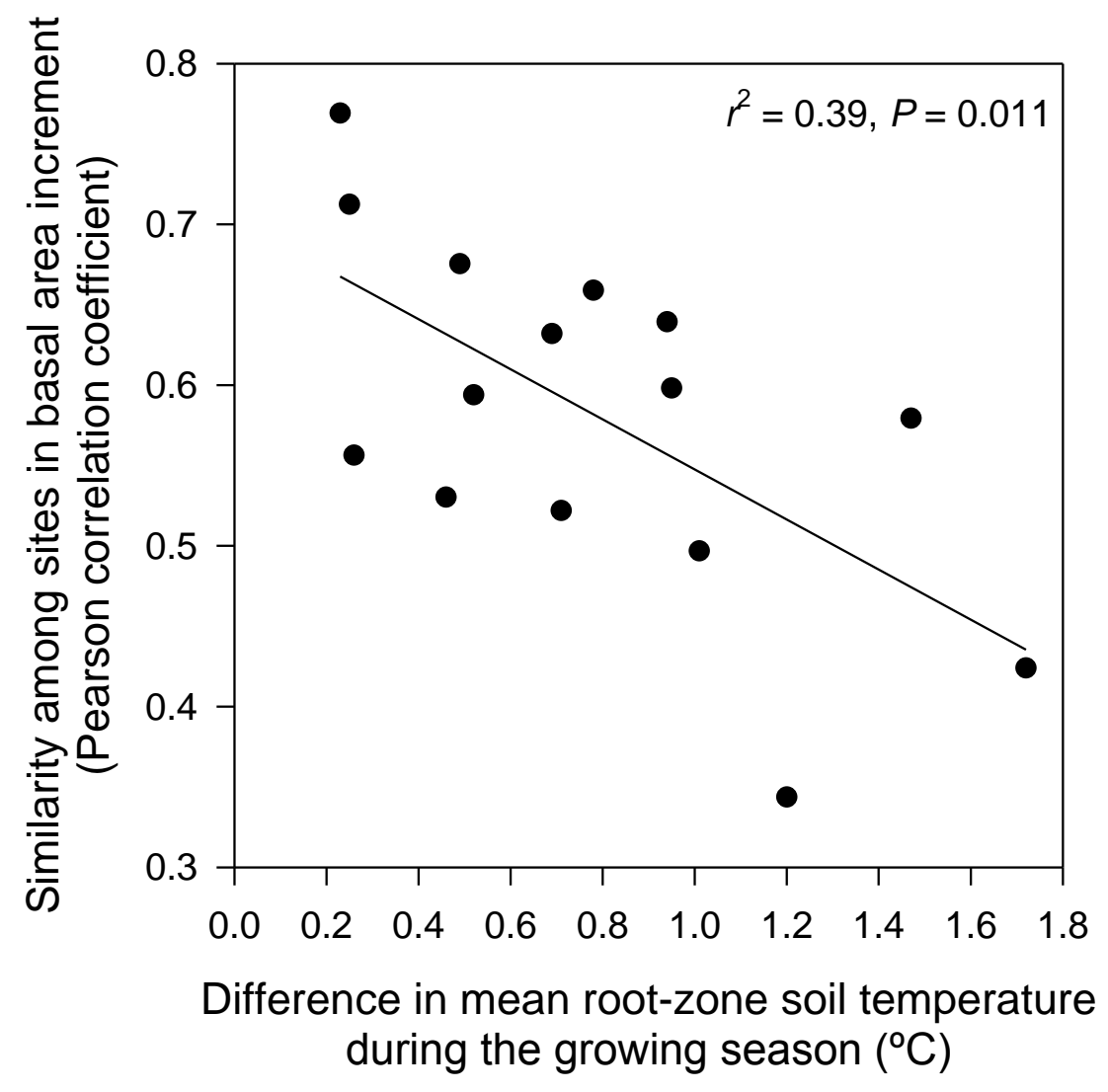

Figure 3 The similarity in basal area increment between treeline sites was negatively related to the difference between sites in root-zone soil temperatures during the growing season 


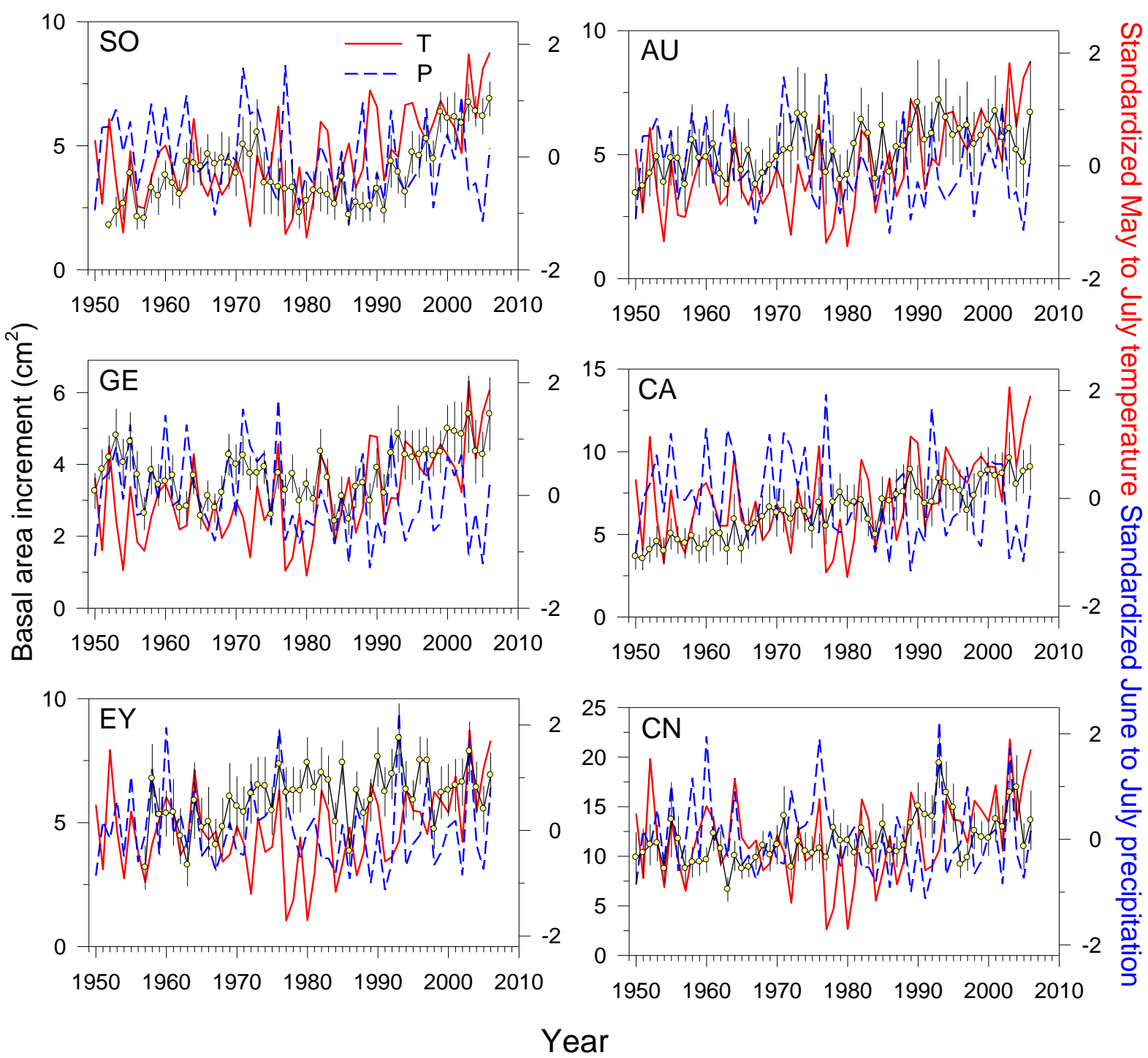

Figure 4 Climatic trends (standardized data) during the growing season and observed values of basal area increment (bars are standard errors) in the six studied treeline sites. Site codes are as in Table 1. Climate variables are mean May to July temperatures (T, red continuous line) and summed June to July precipitation (P, blue dashed lines) 


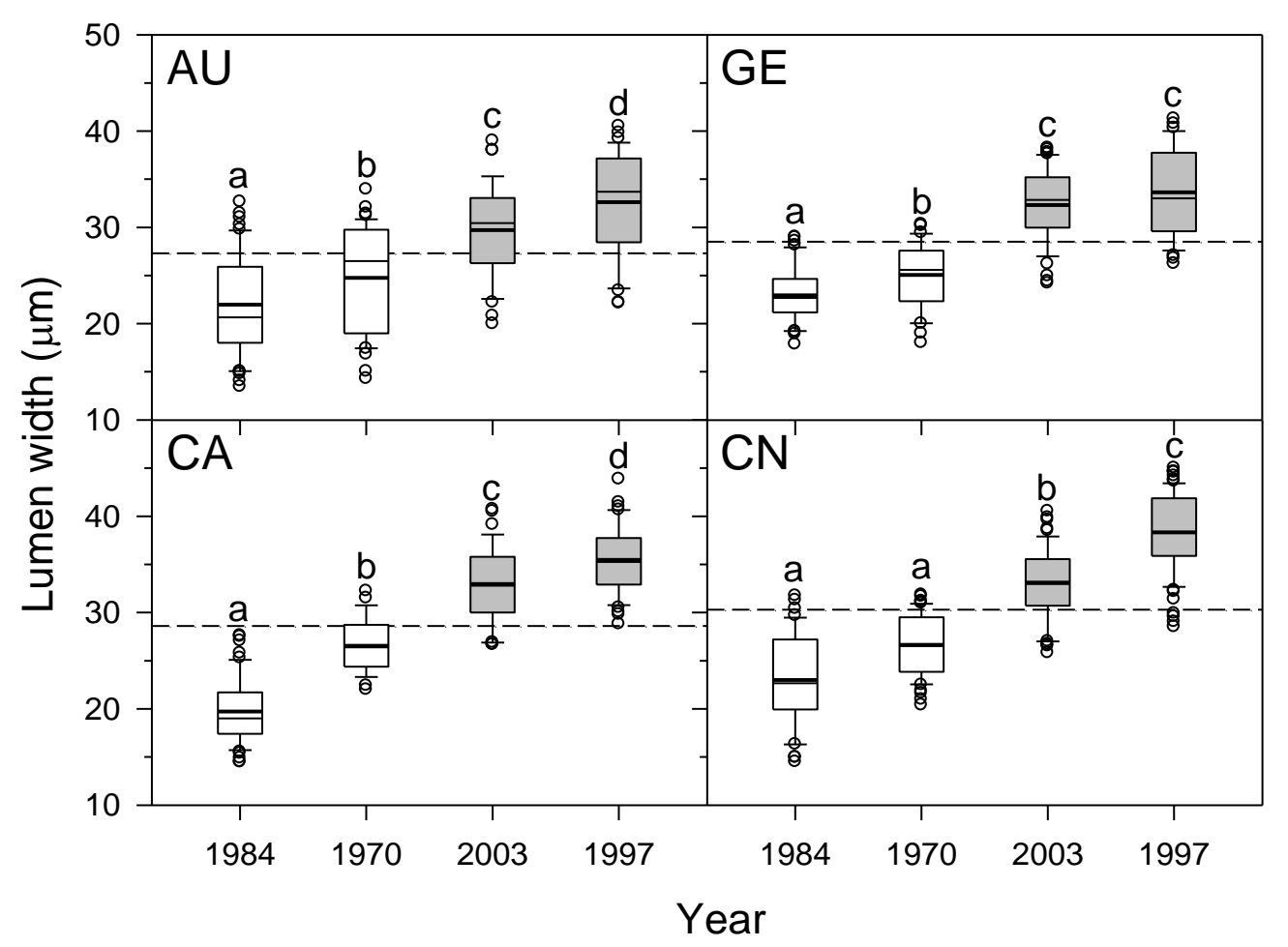

Figure 5 Lumen transversal width values of earlywood tracheids for the four study treeline sites with available wood-anatomical data (AU, GE, CA, CN) and considering four years with contrasting spring temperature conditions (cold spring conditions -empty bars- in years 1970 and 1984; warm spring conditions -filled bars- in years 1997 and 2003). The years are arranged from the coldest (1984) to the warmest spring (1997). The box plots show the mean (thick line) and median (thin line) values. The horizontal dashed lines show the mean lumen widths values for each site. Different letters correspond to significant differences among years within each site $(P<0.05$, SNK test) 


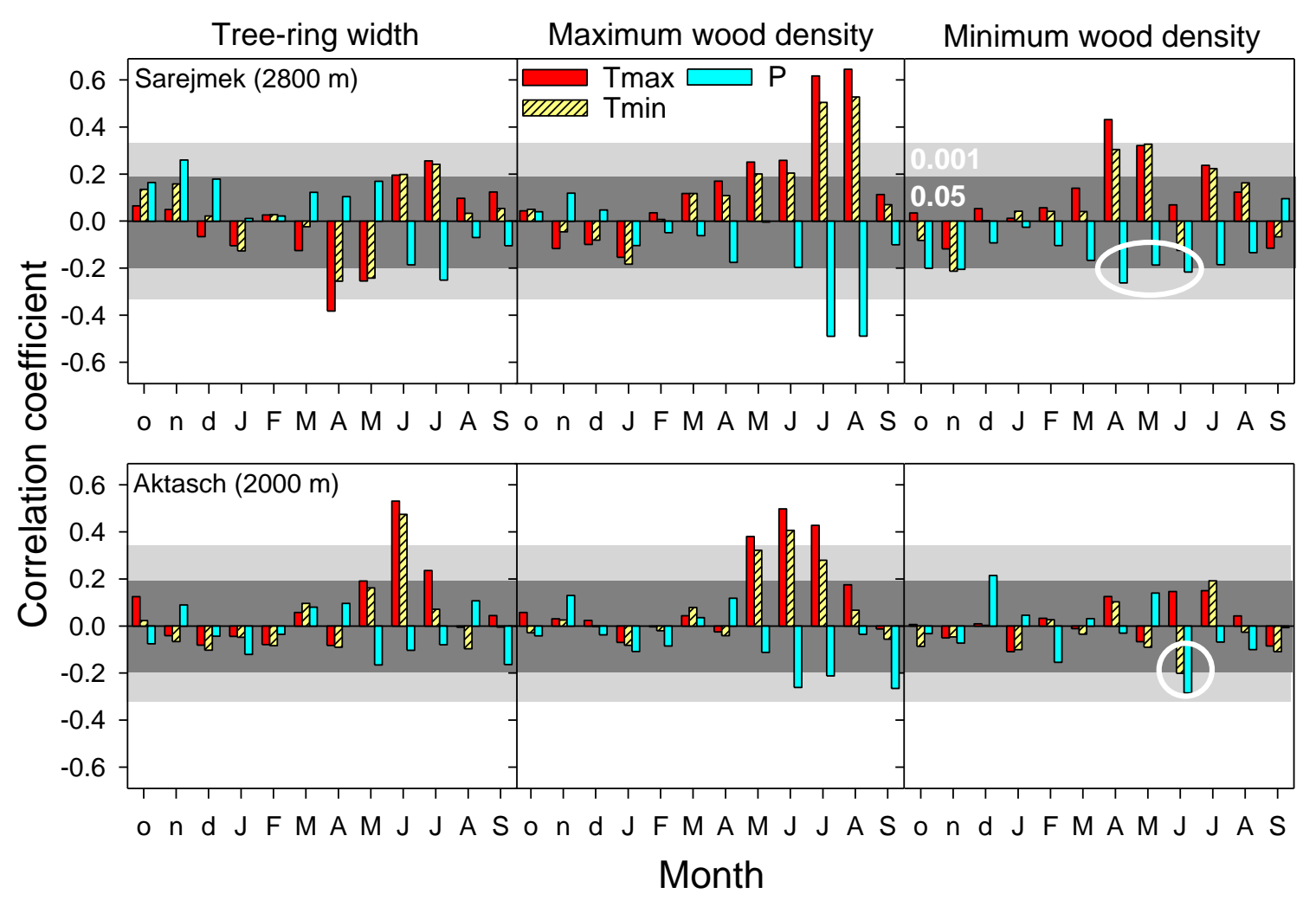

Figure 6 Growth-climate relationships evaluated at two treeline sites from transitional mid-latitude areas subjected to both temperature and potentially water constrains on growth. These associations are based on the correlations observed between monthly climatic variables (Tmax, mean maximum temperature; Tmin, mean minimum temperature; $\mathrm{P}$, precipitation) and tree-ring data (width, maximum and minimum wood density). Months abbreviated either by lowercase or uppercase letters correspond to the prior or concurrent years, respectively. The different grey shadings indicate the two used significance levels $(0.05,0.01)$. The white ellipses highlight the negative associations between growing-season precipitation (April to June) and minimum wood density 